\title{
ATHENAGORAS ON THE DIVINE NATURE: THE FATHER, THE SON, AND THE RATIONAL
}

\author{
D. JEFFREY BINGHAM *
}

Southwestern Baptist Theological Seminary

\begin{abstract}
This essay demonstrates that Athenagoras' theology is primarily concerned, not with the creative activity of God, as L.W. Barnard has argued, but rather with the immateriality of the divine nature and the unity of the Father and the Son. It is this two-fold basis of distinction and unity that makes the apprehension of God possible only by mind and reason. Since the divine nature is heavenly and immaterial, such apprehension cannot occur in the physical realm as promoted in pagan worship, but must take place in the mind through the Son, who is the Logos or Mind, the Reason and Wisdom of the Father. Athenagoras' assertion that the immaterial God can only be apprehended by reason emphasizes the distinction between God and matter, while the unity of the Father and Son in God's acts and teachings highlights the role of reason in the soul's apprehension of the divine. One must be conformed to the Son, who is the Reason of God, in order to apprehend God the Father, and Athenagoras evokes the ethical dimension of reason in the soul's apprehension of the divine. As the soul follows the Son in obeying his teachings, it is conformed to the Son, thereby becoming rational and engaging in rational worship, focusing on the heavenly rather than the earthly. Thus it is in ethical conduct that Christians are essentially pure in spirit and rational in worship, as they are directed by the Son, who is unified with the Father, to apprehend the immaterial God.
\end{abstract}

KEYWORDS: Athenagoras, Creator, immaterial, eternal Son-ness, ethics

In his article, 'God, the Logos, the Spirit and the Trinity in the Theology of Athenagoras', L. W. Barnard wrote the following words regarding Athenagoras' main concerns when it came to the doctrine of a God:

The heart of Athenagoras' belief was the unique, creative activity of God. He held that the purpose of life was an inseparable companionship with the ultimate realities, an unceasing and exultant contemplation and service of the Creator as $\mathrm{He}$ is in Himself, and that contemplation would be the Christian's lot for all eternity (Barnard 1970: 79).

* D. JEFFREY BINGHAM (PhD 1995, Dallas Theological Seminary) is Dean of the School of Theology and Professor of Theology at Southwestern Baptist Theological Seminary. Email: jbingham@swbts.edu. 
In this article, I intend to take issue with this characterization of the apologist's main theological interests. In particular, I hope to demonstrate that it is not God as Creator that is his first interest, but the divine nature as immaterial. Certainly, God's creative activity is emphasized. I do not intend to minimize this. But, against the pagans, God's immateriality comes to the fore. Moreover, I also will take issue with Barnard's belief that 'contemplation' of the Creator is the purpose of life. If by 'contemplation' Barnard means the cultivation of concentration upon God as Creator or the cultivation of the awareness of God as Creator, the harnessing of one's mind so that one's thoughts are consumed with God, I think we need to look more closely at Athenagoras' own text, the Legatio or Plea. ${ }^{1}$ My own understanding is that Athenagoras has a much more ethical notion of life's purpose.

Athenagoras, the Christian apologist writing about 176, was a frustrated man. And with good reason. He and his community had been falsely accused of ideologies and practices unacceptable to any godly society: Atheism, Thyestean banquets, and Oedipean intercourse (Legatio 3.1). Rome regarded itself as such a society, and with the developing rumor that the Christians engaged in such crimes, the Romans felt obligated to cleanse their world of these barbarians, these humans perceived to be worse than savage beasts.

Our apologist concedes that if these rumors were true, such practices and beliefs would be perversions at odds with even beasts, and such people who engaged in them should be expunged from the earth (Legatio 3.1). He writes that not even wild animals engage in these atrocities:

Even animals, however, do not eat members of their own kind; and they mate in accordance with the law of nature and at the one season appointed for the begetting of offspring — not for any licentious purpose; and they also know by whom they are benefited (Legatio 3.1).

Each of the charges against Christians is denied to be the conduct of even savage beasts: they are not cannibals; they mate in accordance with nature and propriety; they acknowledge their benefactor.

The denial that even beasts are atheists, comes in the last phrase: 'they also know by whom they are benefited' (Legatio 3.1). It is the charge of atheism that bothers Athenagoras most, and the indictment to which the other two are integrally related. And for him, the root of atheism is the failure to acknowledge one's true, ultimate Benefactor.

This is the crux for him: True acknowledgement; True Benefactor. He is frustrated, yes, because Christians are perceived as holding separate from 
this crux, but also because of the grounds upon which the perception rests. The Christians are perceived as impious because they do not sacrifice. This is a thorn under his skin because although Christians do not sacrifice, he believes they perceive of God more accurately than do the Romans. In short, they are better theologians, but they are not recognized for their accuracy in theologizing. Rather than measuring piety in terms of precise doctrines and doctrinal reasoning about the divine nature, his accusers measure piety in terms of sacrifices. He writes:

The majority of those accusing us of atheism... have not even the foggiest notion of the nature of God, are ignorant of scientific or theological doctrine and have no acquaintance with them, and measure piety in terms of sacrifices... (Legatio 13.1).

It is the superiority of Christian theologizing to which he appeals in order to persuade the emperors that he and his community are not atheists. Not only does he deem the doctrinal detail to be impressive, but also the foundation for the doctrines-they are God-taught. That is, the Christian conception of the divine nature is divinely-taught. He writes:

Do not be surprised that I go through our teaching in detail. I am making my points carefully to prevent you from being carried away by law and irrational opinion and to put you in a position to know the truth. For we can persuade you that you are not dealing with atheists precisely through the doctrines which we hold-doctrines not man-made but ordained and taught by God (Legatio 11.1).

Thus, Athenagoras is frustrated because Christians are not credited with a piety that arises from doctrine and rationality. As a matter of fact, he considers his community to be entirely rational. It is the Romans, his accusers, who are irrational. The Christians, in proper theological reflection, perceive of God in a manner most rational. 'But surely', he says,

it is not rational for them to apply the term atheism to us who distinguish God from matter and show that matter is one thing and God another and the difference between them immense; for the divine is uncreated and eternal and can be contemplated only by thought (voũs) and reason (גóyos). Whereas matter is created and perishable (Legatio 11.1).

The implication is that Christians are the pious rationalists because they apprehend God in a way conducive to apprehending the divine: by thought and reason. In Greek thought, which in part informs his theology, nous translates as thought or mind. 'Most often', as Stephen Menn notes, 
nous is what someone possesses when he acts or thinks rationally, the habit or virtue of rationality, roughly synonymous with phronesis. This sense is presupposed in the idioms noun echein and noun ktasthai, to possess or acquire reason, to be or become rational. Nous in this sense should be translated as 'reason' or 'intelligence'; it is seriously misleading to translate it as 'mind' (Menn 1992: 555).

We see the same emphasis later in Athenagoras' apology when he develops the Christian position as a religion not focused upon sacrifices or fragrances. Christianity is to be contrasted with pagan religion which measures 'piety in terms of sacrifices' to the gods of the cities (Legatio 11.1). The 'Artificer and Father of this universe', in the conviction of our apologist, does not need incense or blood (Legatio 13.2). 'The best sacrifice to him', he insists,

is for us to know who stretched out the heavens and gave them their spherical form and established the earth as a centre, who brought together water into seas and divided the light from the darkness, who adorned the sky with stars and caused the earth to make every seed spring up, who made animals and formed man (Legatio 13.2).

Thus Athenagoras summarizes that true worship, in essence, is a knowledge of God that is true, and does not imagine him to be material: 'what is required is to offer up our rational worship as an unbloody sacrifice' (Legatio 13.4). And again, when Athenagoras criticizes the pagans who, he is willing to say, theologize ( $\theta \varepsilon$ coloyovoov), however poorly, in their myths, he states that ultimately, their myths 'do anything but treat of God' (Legatio 22.5). Consequently, the pagans theologize, but in doing so, miss a true conception of God, which apprehends him only by reason as immaterial. They theologize by sacrificing, and thus their gods are finite, earthly and corporeal. He says that

They fail to see the greatness of God and are unable to rise up to it by reason (for they are not attuned to the heavenly realm). They have fixed themselves on

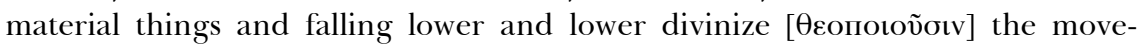
ments of the elements (Legatio 22.12).

Here, as above, a true theology, a true apprehension of the divine, takes place by reason, which is a rising up to the heavenly realm, rather than by a descent to the material elements. We are not surprised to find him saying, then, towards the end of his apology, that Christians 'are servants of reason and not its masters' (Legatio 35.6).

We are well-positioned now to draw together some features of Athenagoras' idea of the divine nature which is apprehended only by reason and mind. It is clearly founded on a distinction between God and matter. For Athenagoras, that means a distinction between that which is uncreated, 
eternal, and unchanging and that which is created, perishable, unstable, and changeable (Legatio $4.1 ; 20.1 ; 22.3$ ). In various metaphors, this distinction is expressed as the difference between Artificer and elements (Legatio 16.4), Potter and clay (15.2), the Ruler and the ruled (22.3), or Pilot and ship (22.12). It is this distinction to which he constantly returns. For instance, in contrasting the Christian belief with that of the Romans which variously conceives of the gods as demons or matter or humans, he objects to the Empire's persecution of his community. In light of the Roman conceptions, he asks,

would it make sense to have us banished because we have a doctrine which distinguishes God and matter and their respective substances? (Legatio 24.1).

In the language of Euripides, the distinction becomes one between God and his works. The works, which are seen, are not to be confused with God, for they are not the divine substance. The visible works merely provide a glimpse of the divine substance which is unseen, invisible (Legatio 5.1-2). Ultimately, the Christian distinction conceives of the gap between Being and non-being 'since it is not Being that is created, but non-being' (Legatio 4.2).

The Roman populace, in his opinion, exercises an inability to distinguish what is matter, what is god, and what a great gulf there is between them' (Legatio 15.10). The Christians, on the other hand, are consistent with Plato who 'teaches that that which always is, the intelligible, is uncreated, whereas that which is not, the perceptible, is created, having a beginning to its existence and an end' (Legatio 20.2). The Christians:

do distinguish and divide the uncreated from the created, being from non-being, the intelligible from the perceptible, and... give each of them its proper name (Legatio 15.1).

Here then we get a hint as to what the Christian superiority is in theological thought: distinguishing and dividing God from matter, from creation, from the perceptible, visible elements.

For Athenagoras, in his Roman climate, this distinction is developed basically only against one competing idea: idolatry (the worship of gods as statues or figures of wood, metal, stone) through bloody or fragrant offerings and sacrifices. In this vein, he summarizes:

Consequently, if we should recognize material forms as gods, it will be seen that we are blind to him who is truly God by equating perishable and corruptible things with that which is eternal (Legatio 15.4). 
The soul that equates the eternal divine nature with perishable things is one which looks down to earthly things rather than up to heavenly things. This soul fails to be 'directed by reason', it fails to be pure spirit, and becomes directed by fantasy, illusion, unsound teaching, and demons which 'are greedy for the savour of fat and the blood of sacrifices' (Legatio 27.1-2).

So when our apologist speaks of the divine nature being contemplated 'only by thought and reason' or our rising 'up to it by reason', it is a recognition of the one true Benefactor, who is immaterial and matter's Maker. Such a concept is contrary to the illusory manner of the Romans. But there is something else. For Athenagoras, the existence and nature of the Son of God is in complete continuity with the divine nature. We see in the first part of his famous theological summary: He believes in a 'God who is uncreated, eternal, invisible, impassible, incomprehensible, and infinite, who can be apprehended by mind and reason alone' (Legatio 10.1). But Christians also acknowledge 'a Son of God' and no one should think it absurd that God would have a Son, for the Son is 'the reason (lóyos) of the Father... the mind (voũs) and reason (lóyos) of the Father' (Legatio 10.2). The Son was not brought into existence, for 'from the beginning the God who is eternal mind (voũs), had the Reason (ไoүıкòs) within himself from eternity' (Legatio 10.3).

What is important for us to see is that in the mind of our apologist, the notion of the divine Son flows from his notion of the divine nature. Given the latter, there must exist the former. The Johannine language, or a tradition of sayings of the Lord, seems to have influenced him in his conception of the essential unity between Father and Son. Within the immediate context of his discussion, he writes that such unity is expected, 'the Father and the Son being one' and 'the Son being in the Father and the Father in the Son' (Legatio 10.2). This language brings to mind John 10:30 and John 14:11. Of course, also, his language of the Reason or Logos being within the Father since the beginning echoes John 1:1.

Although we have briefly seen the Christian sources of his theology, obviously both Platonic and Pre-Socratic sources also influenced his thought. In particular, we think of the Greek idea of nous as that which ordered heaven and earth. Let us quickly view some places where the idea is put forth. Plato, for example, says in the Philebus that 'all the wise agree that nous is king for us of heaven and earth' (28c6-8). In Laws, the Athenian stranger says recent philosophers have retrieved the older notion that 'nous

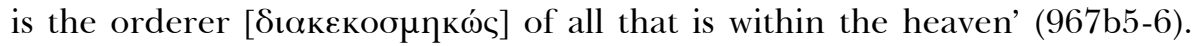
Furthermore, Plato in the Timaeus presents a hypothetical account of the

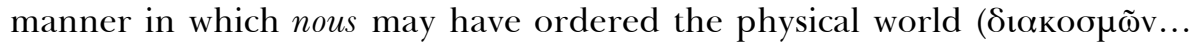
oủpavòv) (37d5-6). Finally, Plato in the Phaedo refers to the 'wise' who pre- 
ceded him as teaching that nous was the orderer ( $\delta 1 \alpha$ koo $\mu \tilde{\omega} \mathrm{v})$ of all things (97c1-2).

Our apologist's view of the divine nature combines, then, an essential distinction between God and matter, but also an essential unity between God the Father and God the Son, who is the Mind, Reason, and Wisdom of God. It is this two-fold basis which makes God one who is apprehended only by mind and reason. Recognition of him must not take place in idols assisted by fragrance and sacrifices but in a soul directed by reason, or in what seems to be a parallel notion for Athenagoras, a pure soul.

It is significant that immediately following his development of the unity between Father and Son, he cites as doctrines taught by God, a saying of the Son from Matthew 5:45. This saying, which is doctrinal, proves in his mind the theism of the Christians. It reads:

I say to you, love your enemies, bless them who curse you, pray for them who persecute you, that you may be sons of your Father in heaven who makes his sun to rise upon the evil and the good, and sends rain on the just and the unjust (Legatio 11.2).

Notice the occurrence of the phrase, 'that you may be sons of your Father in heaven who makes his sun to rise... and sends rain...' Here God is said to be positioned in heaven, echoing an earlier usage of Isaiah 66:1 where heaven is identified as God's footstool. This biblical language has informed his repeated teaching on reasonable worship as a looking up to heavenly things (Legatio 22.12; 27.1-2). Also the Father is identified as the one who orders, adorns, and rules the sun and rain. And the implication from his previous discussion is that the Agent for this administration is the Son. Furthermore, this phrase makes being a son of the Father conditional on obeying the teachings, the doctrines of the Son of the Father. Or, one could say it makes obedience to the doctrine of the Mind, Reason, or Rationality of the Father foundational to rational worship. To be a son one must follow the Son. To be rational one must follow the Mind and Reason of the Father.

So, what does it mean to follow the Father's Mind? It means, according to the Son's words, to love, bless, and pray for those who are your adversaries. It means to be the benefactor of those who oppose you. Just as the Father through the Son benefits both the just and the unjust, the good and the evil, so those who wish to be sons must do the same. The Father's eternal Rationality, his Word and Son, benefits without prejudice. This then becomes essential to apprehending God through mind and reason, this is rational worship, this is the soul directed by reason, because this is what the Father's Reason does.

What Athenagoras has done is to place the Son's agency of the Father's acts into the Son's own statements about the Father. There is such unity be- 
tween the two that he does not even introduce it as a saying of the Son in particular. It is a teaching of God.

And Athenagoras has made rational worship ethically centered. This becomes very pronounced when he contrasts members of his community with those philosophers and rhetoricians who focus on reasoned discourse. Within his community, our apologist points out, one could find common people, unskilled in rhetoric and logic, who 'cannot establish by reasoned discourse the usefulness of their teaching' (Legatio 11.4). But they have made their focus, against the rhetoricians, the doing of good deeds rather than the rehearsal of words. It is here in their deeds that they are 'pure in soul' (Legatio 11.3), again in contrast to those who focus upon words. It is in ethical conduct that Christians are essentially pure in spirit, rational in worship. For here they are heavenly focused rather than earthly, because they know they will render account above for life here below (Legatio 12.1-3).

Athenagoras' concept of the divine nature pivots around two poles. The first is the distinction of God from matter, as the eternal, uncreated One apprehended only by reason. But while the first stresses God's separation, the second highlights the unity of the Father and Son in God's acts and teachings. Here is the perceived superiority in Christian theological thinking.

Through this distinction and unity comes an interesting perspective on rational or spiritual worship. With our modern heritage, we are often prone to focus upon reason's intellectual dimension. Our apologist challenges us to recall the ethical dimension of reason as we seek to apprehend the divine nature. He also provides us with an early second-century model of the christological center to the divine nature, and the divine center to christology. The historical Jesus is not his emphasis. Even his teachings are said to be God's. This is because Athenagoras is developing the divine nature and so limits his christology to Christ's Son-ness, because it is Son-ness that is essential to God-ness. Already, prior to the fourth century, Son-ness is eternal, and essential to the superior Christian conception of the divine nature. This is the rational, the pure conception.

\section{Bibliography}

Barnard LW (1970) God, the Logos, the Spirit and the Trinity in the Theology of Athenagoras. Studia Theologica 24(1): 70-92.

Burnet J (ed) (1903). Platonis Opera, volumes 1-7. Oxford: Oxford University Press.

Menn S (1992) Aristotle and Plato on God as Nous and as the Good. The Review of Metaphysics 45(3): 543-573. 
Schoedel WR (ed) (1972) Athenagoras: Legatio and De Resurrectione. Oxford: Oxford University Press 